\title{
PENGEMBANGAN FILM ANIMASI 3 DIMENSI TUDE THE MOVIE-PENTINGNYA MENCUCI TANGAN YANG BENAR
}

\author{
Ni Kadek Dwi Trisna Rahayu ${ }^{1)}$, I Made Gede Sunarya ${ }^{2)}$, I Gede Bendesa Subawa ${ }^{3)}$ \\ Program Studi Pendidikan Teknik Informatika \\ Jurusan Teknik Informatika \\ Fakultas Teknik dan Kejuruan \\ Universitas Pendidikan Ganesha \\ Email : nikadekdwitrisnarahayu19@undiksha.ac.id ${ }^{1}$, sunarya@undiksha.ac.id ${ }^{2}$, bendesa.subawa@ undiksha.ac.id $^{3}$
}

\begin{abstract}
Abstrak-Anak-anak usia sekolah cenderung memiliki pengetahuan yang minim mengenai bagaimana mencuci tangan dengan benar. Padahal, tangan merupakan salah satu bagian tubuh yang paling rentan mengandung kuman dan bakteri karena dipakai untuk menyentuh dan memegang benda. Menimbang pentingnya kesadaran dan pengetahuan mengenai cara mencuci tangan yang benar, penelitian ini bertujuan untuk mengembangkan film animasi 3 dimensi yang mampu mengenalkan budaya cuci tangan yang baik kepada anak-anak usia sekolah. Dengan demikian, Film Animasi 3 Dimensi - Tude the Movie Pentingnya Mencuci Tangan Yang Benar pun dikembangkan dengan jenis penelitian Research \& Development (R\&D). Metode Multimedia Development Life Cycle digunakan dalam proses pengembangan film animasi yang terdiri dari 6 tahapan, yaitu concept,design, material collecting, assembly, testing, dan distribution. Guna menjamin kualitas dari konten dalam film animasi ini, beberapa pengujian pun dilakukan, di antaranya uji ahli isi yang mendapatkan hasil $100 \%$, uji ahli media yang mendapatkan hasil $100 \%$, serta uji respon pengguna yang dilakukan terhadap 50 responden anak usia sekolah yang mendapatkan hasil $98 \%$ sangat positif dan $2 \%$ positif. Dengan demikian, diperoleh hasil bahwa film animasi ini memeroleh responyang sangat baik dari responden.
\end{abstract}

\section{Kata Kunci-animasi 3 dimensi, cara mencuci tangan}

Abstract-Children in their school age tend to have very little knowledge about how to wash their hands properly. In fact, hands are one of the most vulnerable parts of the body to contain germs and bacteria as they are used to touch and hold objects. Considering the importance of having the awareness and knowledge about how to wash hands properly, this study aimed to develop a 3-dimensional animated film that was able to introduce good hand washing culture to the children. Thus, Tude the Movie - The Importance of Proper Hand Washing 3 Dimensional Animated Film was developed with the type of Research \& Development (R\&D) design. The Multimedia Development Life Cycle method was used in the animation film development process which consisted of 6 stages, namely concept, design, collecting material, assembly, testing, and distribution. In order to guarantee the quality of the content in this animated film, several tests were carried out, including the content expert test and the media expert test which both got very good results. Then, user response tests was also conducted on 50 school-age respondents with very positive as the major results. Thus, the results indicated that this animated film received a very good response from the respondents.

Keywords-3D animation, how to wash hands

\section{PENDAHULUAN}

Perkembangan teknologi di Indonesia sangatlah cepat, menempatkan Indonesia sebagai pengguna (user) teknologi dan informasi terbanyak mengingat besarnya jumlah penduduk Indonesia. Dilihat dari populasi dan jumlah penduduk di Indoneisa yang tergolong banyak, maka jumlah anak usia sekolah juga tergolong banyak. Sehingga banyak kebutuhan masyarakat Indonesia khususnya anak usia sekolah yang harus terpenuhi dengan adanya perkembangan teknologi tersebut, salah satunya dalam memberikan sarana hiburan dan edukasi. Berbagai jenis sarana hiburan dan edukasi yang ada, salah satunya yang sangat menarik bagi anak usia sekolah yaitu film animasi.

Animasi adalah gambar bergerak yang dibentuk dari sekumpulan objek yang disusun secara beraturan dengan kecepatan tertentu [1]. Secara garis besar, animasi dibagi menjadi dua kategori, yaitu animasi 2 dimensi dan 3 dimensi, yang berbeda dari segi kualitas tampilan yang dihasilkan. Ciri khas pada animasi 2 dimensi yaitu terdapatnya garis besar pada 
e-ISSN: 2685-7006 | p-ISSN: $2252-9063$

Kumpulan Artikel Mahasiswa Pendidikan Teknik Informatika

(KARMAPATI)

Volume 10, Nomor 2, Tahun 2021

\section{KดRMAPคTI}

setiap objek yang ada. Selain itu, objek juga terlihat lebih tegas, namun terkesan pipih, datar dan kurang bervolume. Contoh animasi 2 dimensi seperti Naruto, One Piece, Dora theExplorer dan SpongeBob SquarePants. Sedangkan pada animasi 3 dimensi, umumnya tidak akan terlihat outline pada objek-objek yang ditampilkan. Warna lebih cerah dengan tekstur yang lebih lembut dan seolah mengilap, dan juga terdapat volume setiap objek. Contoh dari animasi 3 dimensi seperti Frozen, Finding Nemo. Film animasi Adit Sopo Jarwo dari Indonesia juga termasuk kategori film animasi 3 dimensi [2].

Film animasi 3 dimensi telah digunakan secara luas untuk industri hiburan, permainan, penyampaian informasi, maupun pendidikan. Dampak baik dari film animasi 3 dimensi ini selalu memiliki makna dan pesan yang ingin disampaikan kepada audiens atau masyarakat. Adanya peran dari karakter yang diciptakan padafilm animasi mampu mempengaruhi audiensnya untuk mengikuti atau justru melakukan hal yang sama, terutama pada anak yang menonton film animasi tersebut. Selain dampak baik pada film animasi juga terdapat dampak buruk pada film animasi 3 dimensi yang dimana mempengaruhi sifat dari anakanak, dikarenakan kebanyakan anak-anak menonton film animasi 3 dimensi dari kartun luar negeri yang dimana banyak menampilkan kekerasan dan omongan yang kasar. Tetapi tidak semua film animasi buruk, banyak terdapat film animasi yang mengedukasi dan memberikan informasi yang baik. Salah satu informasi yang harus tersampaikan kepada anak adalah terkait tata cara pergaulan di lingkungan bermainnya.

Memahami pergaulan pada anak usia sekolah sangatlah luas, seperti pada lingkungan keluarga, lingkungan bermain maupun lingkungan sekolah. Lingkungan bermain membuat anak usia sekolah sangat rentan terjangkit penyakit. Salah satu anggota tubuh yang menjadi media penularan berbagai penyakit yaitu tangan. Tangan kita selalu menyentuh dan memegang segala bendayang tidak tahu kebersihannya [3]. Oleh karena itu, perlu mencuci tangan secara rutin dan menyeluruh dengan minimal 20 detik menggunakan sabun dan air bersih yang mengalir. Setelah itu, keringkan tangan menggunakan kain yang bersih ataupun tisu [3].

Mencuci tangan menggunakan sabun yang tidak benar masih tinggi ditemukan pada masyarakat umum, khususnya pada anak usia sekolah. Anak usia sekolah biasanya hanya mengetahui mencuci tangan yang penting tangannya basah saja, padahal mencuci tangan menggunakan air saja belum cukup untuk membunuh kuman-kuman yang ada di tangan. Mencuci tangan dengan air yang mengalir dan menggunakan sabun merupakan cara yang efektif untuk menghilangkan kotoran dan debu dari permukaan kulit sehingga dapat mengurangi jumlah mikroorganismepenyebab dari peyakit yang berupa virus, bakteri dan parasite lainnya [4]. Selain itu, pada saat ini Negara
Indonesia sedang dilanda oleh COVID-19. Mencuci tangan menggunakan sabun dengan benar merupakan salah satu bentuk pencegahan yang sederhana tetapi efektif untuk memutuskan rantai penyebaran COVID-19 (Wahyuni, 2020). Dengan demikian diperlukan pengetahuan dan kesadaran anak bagaimana pentingnya mencuci tangan menggunakan sabun dan bisa diterapkan dalam kehidupan sehari-hari. Jadi, mencuci tangan menggunakan sabun dengan baik harus dilatih sejak dini pada anak, agar anak memiliki kebiasaan mencuci tangan menggunakan sabun dengan benar sehingga terhindar dari penyakit seperti diare. Dengan demikian perlunya informasiinformasi yang membuat anak usia sekolah mengerti pentingnya mencuci tangan menggunakan sabun dengan benar agar terhindar dari penyakit.

Hasil observasi awal yang peneliti lakukan menemukan bahwa $88 \%$ anak usia sekolah jarang mendapatkan informasi terkait cara mencuci tangan dengan sabun dan sebanyak $86 \%$ anak usia sekolah cukup bisa mencuci tangan dengan benar. Dengan demikian, penting bagi mereka untuk dibuatkan sarana edukasi mengenai cara mencucitangan yang benarmenggunakan media film animasi 3D, karena dengan dibuatkannya film animasi 3D mereka lebih mudah memahami pentingnya mencuci tangan yang benar serta cara mencuci tangan dengan benar.

Berdasarkan uraian tersebut, maka diperlukan media edukasi baru yang dapat memberikan pengetahuan kepada anak usia sekolah mengenai pentingnya mencuci tangan menggunakan sabun dengan benar. Salah satu media informasi yang dapat digunakan berupa media film. Media film sekarang bukan hanya sebagai media hiburan melainkan dapat juga sebagai media informasi,pendidikan, promosi, dan masih banyak lainnya [5]. Media informasi yang peneliti kembangkan yaitu film animasi 3 dimensi yang nantinya akan menceritakan bagaimana pentingnya mencuci tangan menggunakan sabun, dengan ini anak usia sekolah lebih tertarik untuk melihat, mendengarkan dan langsung cepat menangkap informasi mengenai pentingnya mencuci tangan menggunakan sabun dengan benar.

Media berupa film animasi 3 dimensi dipilih karena beberapa studi sebelumnya membuktikan bahwa film animasi mampu menjadi media edukasi yang informative sekaligus menghibur bagi anak.

Dengan demikian, berdasarkan pemaparan permasalahan tersebut, peneliti tertarik untuk merancangdan mengembangkan sebuah animasi 3 dimensi tentang Pentingnya Mencuci Tangan Menggunakan Sabun yang berjudul "Pengembangan Film Animasi 3 Dimensi Tude The Movie - Pentingnya Mencuci Tangan Yang Benar." Selain mengembangkan film animasi 3 dimensi ini, penelitian ini juga mencari tahu respon yang diberikan oleh anak usia sekolah sebagai target dari film ini. 


\section{KAJIAN TEORI}

\section{A. Film}

Menurut UU No. 8 Tahun 1992 definisi film adalah karya cipta dan seni yang merupakan media komunikasi massa pandang- dengar yang dibuat berdasarkan atas sinematografi dengan direkam pada pitaseluloid, pita video, piringan video dan/atau berhak atas hasil penemuan teknologi lainnya dalam segala bentuk, jenis dan ukuran melalui proses elektronik atau proses lainnya, dengan atau tanpa suara yang dapat dipertunjukkan dengan sistem proyeksi mekanik dan lain sebagainya. Film adalah rangkaian gambar yang bergerak membentuk suatu cerita atau juga biasa disebut movie atau video [6].

\section{B. Jenis-Jenis Film}

Menurut Marcel Danesi dalam buku Semiotik Media, menuliskan tigajenis atau kategori utama film, sebagai berikut.

a. Film Fitur

Film fitur merupakan karya fiksi, yang strukturnya selalu berupa narasi, yang dibuat dalam tiga tahap. Tahap praproduksi merupakan periode ketika skenario diperoleh. Skenario ini bisa berupa adaptasi darinovel, atau cerita pendek, cerita fiktif atau kisah nyata yang dimodifikasi, maupun karya cetakan lainnya, bisa juga yang ditulis secara khusus untukdibuat filmnya.

b. Film Dokumenter

Film dokumenter merupakan film nonfiksi yang menggambarkan situasi kehidupan nyata dengan setiap individu menggambarkan perasaannya dan pengalamannya dalam situasi yang apa adanya, tanpa persiapan, langsung pada kamera atau pewawancara.

c. Film Animasi

Animasi adalah teknik pemakaian film untuk menciptakan ilusi gerakan dari serangkaian gambaran benda dua atau tiga dimensi. Penciptaan tradisional dari animasi gambar bergerak selalu diawali hampir bersamaan dengan penyusunan storyboard, yaitu serangkaian sketsa yang menggambarkan bagian penting dari cerita.

\section{Animasi}

Animasi adalah gambar bergerak yang berasal dari kumpulan berbagai benda yang diatur secara khusus sehingga bergerak sesuai dengan jalan yang telah ditentukan pada setiap hitungan waktu. Objek yang dimaskud adalah gambar manusia, tulisan teks, gambar binatang, gambar tumbuhan,bangunan dan sebagainya. Animasi pada awalnya dilihat dari lukisan di dinding goa. Pada goa tersebut ditemukan gambar - gambar binatang yang dilukiskan denganmemiliki beberapa kaki yang ditumpuk, seperti memperlihatkan jika binatang - binatang itu sedang bergerak. Gambar tersebut memperlihatkan pergerakan binatang seperti bison, babi hutan, ataupun kuda [7].

\section{Teknik Menciptakan Animasi}

Animasi berdasarkan teknik pembuatannya dapat dikategorikan menjadi 3 [7], yaitu sebagai berikut.

a. Stop Motion Animation

Stop-motion animation sering disebut dengan Claymation karena dalam perkembangannya, jenis animasi ini menggunakan tanah liat sebagai objek yang digerakkan. Teknik stopmotion animation merupakan animasi yang dihasilkan dari pengembalian gambar berupa objek yang digerakan setahap demi setahap.

b. Animasi Tradisional

Animasi tradisional sering disebut dengan cel animation. Hal ini disebabkan karena teknik pengerjaannya dilakukan pada celluloid transparent yang sekilas mirip dengan tranparasi OHP (Overhead projector) yang sering digunakan. Pada pembuatan animasi tradisional,setiap tahapan gerak digambar satu persatu di atas cel.

Pesatnya perkembangan teknologi komputer, pembuatan animasi tradisional dikerjakan dengan menggunakan komputer. Saat ini teknik pembuatan animasi tradisional yang dibuat dengan menggunakan komputer lebih dikenal dengan istilah animasi 2 Dimensi.

c. Animasi Komputer

Animasi komputer secara keseluruhan dikerjakan dengan menggunakan komputer. Dari pembuatan karakter, mengatur gerakan objek dan kamera, pemberian suara, serta pemberian efek semuanya dikerjakan dengan komputer.

\section{E. Animasi 3 Dimensi}

Animasi 3 dimensi (3D) adalah teknik pembuatan animasi pada sebuah bidang uang menggunakan 3 sumbu $\mathrm{X}, \mathrm{Y}$, dan Z sebagai sumbu kedalaman. Objek yang dihasilkkan bisa diputar berdasarkan 3 sumbunya. Umumnya animasi 3D dikerjakan di pada komputer yakni sudah berupa file digital, walaupun untuk memodeling (membuat model karakter dalam animasi 3D) masih diperlukan gambar sketsa manual sebagai acuan [8].

Animasi 3 dimensi merupakan jenis animasi yang menggunakan obyek animasi dalam wujud trimatra yang memperhitungkan karakter obyek animasi, sifat bahan yang dipakai, waktu, cahaya, dan ruang [9]. Animasi 3 dimensi adalah animasi yang berwujud 3 dimensi. Meskipun bukan 
e-ISSN: 2685-7006 | p-ISSN: $2252-9063$

Kumpulan Artikel Mahasiswa Pendidikan Teknik Informatika

(KARMAPATI)

Volume 10, Nomor 2, Tahun 2021

KคRMดPดTI

dalam wujud 3D yang sebenarnya, yaitu bukan sebuah objek 3D yang dapat disentuh dan dirasakan wujud fisiknya, namun dalam wujud 3D dalam layar kaca [10]. Proses produksi animasi 3 dimensi memiliki beberapa tahapan-tahapan dalam pembuatannya, yang terdiri dari modelling, texturing, rigging, skinning, action/animation, lighting, dan rendering.

\section{METODOLOGI}

\section{A. Jenis Penelitian}

Penelitian ini merupakan jenis penelitian pengembangan Research and Development (R\&D) atau metode penelitian dan pengembangan. Research and Development adalah pendekatan penelitian unutuk menghasilkan suatu produk baru atau menyempurnakan produk yang sudah ada [11]. Metode Research and Development adalah metode penelitian yang digunakan untuk menghasilkan sebuah produk tertentu, dan menguji keefektifan produk tersebut [12]. Berdasarkan pengertian ahli di atas bisa disimpulkan bahwa jenis penelitian Research anD Development adalah metode penelitian yang menghasilkan sebuah produk dalam bidang keahlian tertentu.

\section{B. Metode Penelitian}

Metode penelitian yang digunakan dalam penelitian ini adalah metode MDLC (Multimedia Development Life Cycle). Ada enam tahap dalam MDLC, yaitu Concept, Design, Material Collecting,Assembly, Testing, dan Distribution. Pada penelitian ini, peneliti tidak sampai dengan tahap evaluasi. Evaluasi merupakan suatu riset untuk mengumpulkan, menganalisis, dan menyajikan informasi yang berguna mengenai objek evaluasi [17]. Penelitian ini hanya sampai pada tahap pengembangan dan menganalisis respon masyarakat terhadap film animasi Tude The Movie - Pentingnya MencuciTangan Yang Benar yang dikembangkan. Berikut merupakan gambar tahapan model pengembangan Multimedia Development Life Cycle, seperti terlihat pada Gambar 1.

\section{Perancangan Film Animasi}

Pada tahap ini, dalam menggambarkan perancangan dari setiap scene perlu dibuatkan sebuah perancangan mulai dari ide cerita, sinopsis dan storyboard, perancangan karakter serta perancangan perangkat lunak yang akan dipakai dalam pembuatan film animasi 3 dimensi ini.

\section{a. Ide Cerita}

Dalam mencari ide cerita film animasi3 dimensi ini terinspirasi dari film animasi 3 dimensi yang sudah ada, seperti Upin \& Ipin. Ide cerita ini juga terinspirasi dari kurangnya minat masyarakat umum untuk mengetahui informasi bagaimana pentingnya mencuci tanganyang benar, dengan mengangkat ide cerita ini diharapkan masyarakat lebih tertarik untuk mengetahui informasi pentingnya mencuci tangan yang benar dan bisa diterapkan pada kehidupan sehari-hari.

b. Karakter

Perancangan karakter merupakan pembuatan desain tokoh atau karakteryang akan menjadi peran dalam film animasi 3 dimensi ini. Hal pertama yang dilakukan dalam membuat desain karakter adalah menentukan bentukfisik serta penampilan tokoh pada film. Terdapat 7 karakter dalam film animasi ini yang terdiri dari Tude, Pandu, Bryan, Cava, Nana, Arya, dan Dokter Surya.

c. Storyboard

Storyboard adalah sebuah sketsa yang menggambarkan aksi di dalam film, atau bagian khusus film yang disusun teratur dan dilengkapi dengan dialog yang sesuai dengan waktu dan deskripsi adegan. Storyboard memiliki fungsi yaitu untuk menjaga agar film animasi yang dibuat tidak keluar ataupun melenceng dari konsep atau ide cerita yang telah ditentukansebelumnya. Selain itu fungsi dari storyboard yaitu membantu mempermudah para pembuat animasi agar dengan mudah memahami alur. Storyboard yang dirancang oleh peneliti berjumlah 17 scene yang kemudian didikan sebagai da pembuatann film animasi 3 dimensi.

d.

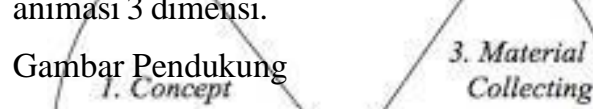

Perancangan gambar pendukung yaitu pembuatan desaîn diluar tokoh ataukarakter sesuai kebutuhan dari film. Gambar pendukung yang dimaksud berupa latar

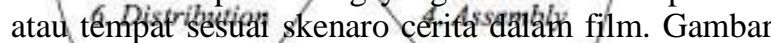
pendukung yang/digunakan dalam film animasi ini terdiri dari Lanangan Puputan Badung, tempat bermain, Puskesmas, da rumah Bryan. ampilan perencanaan gambar pendukung berupa lâtar tempat pada animasi dapat dilihat pada Tabel 1 berikut. 
Tabel 1. Rancangan Latar Belakang

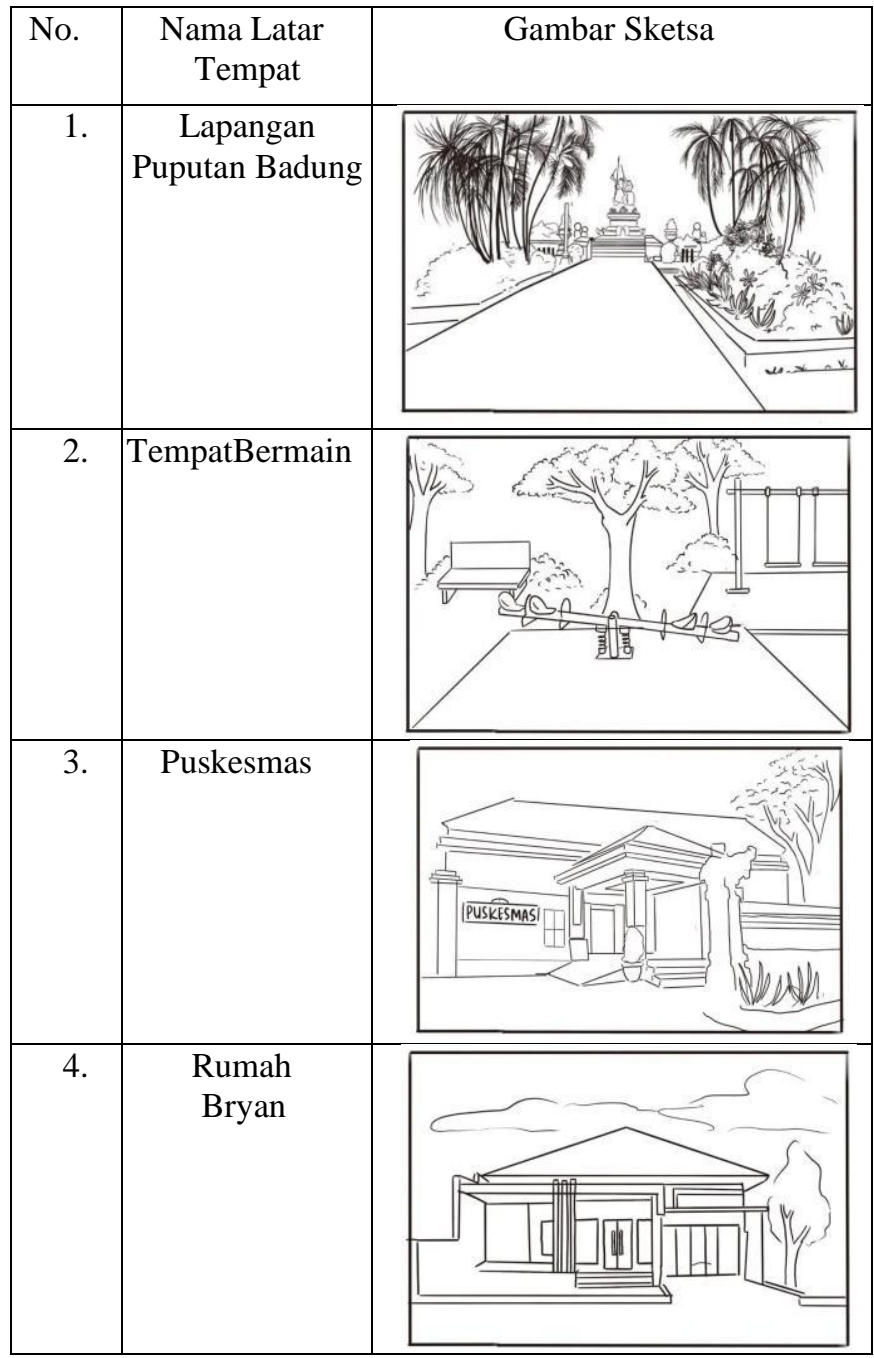

\section{Tahap Produksi Animasi}

Pada tahap produksi film animasi dibuat sesuai kebutuhan dari proses pra-produksi atau perancangan. Adapun hal yang dilakukan di tahap produksi yaitu:

- Modelling

- Texturing
- Rigging

- Skinning

- Action/Animation

- Lighting

- Rendering

\section{E. Tahap Pasca Produksi}

Tahap ini dilakukan setelah tahap produksi film 3 dimensi selesai dilakukan. Tahap ini terdiri atas tahap perekaman dimana storyboard direkam dengan pengisi suara dan tahap penggabungan dimana seluruh adegan yang telah dibuat dan dirender disatukan laludigabungkan untuk menghasilkan suatu produk film animasi 3 dimensi yang utuh. Tahap penggabungan dilakukan dengan bantuan aplikasi Adobe Premiere ProCS6 dan Adobe Affter Effect.

\section{F. Pengujian (Testing)}

Pada tahap ini dilakukan pengujian pada film animasi yang dibuat. Tahap pengujian dilakukan tidak setelah aplikasi jadi seluruhnya, tetapi dilakukan per scene atau dilakukan ditengahtengah proses pembuatan. Film animasi harus berjalan dengan baik pada perangkat komputer manapun. Apabila ada kesalahan, maka perbaikan dilakukan. Kemudian, jika sudah berjalan sesuai dengan rancangan dan tujuan, proses akan masuk ke tahap selanjutnya yaitu penyelesaian dan distribusi. Pada tahap testing, terdapat uji ahli isi, uji ahli media, dan uji respon pengguna.

Uji ahli isi dipergunakan sebagai standar untuk mengetahui kesesuaian isi dari Film Animasi 3 Dimensi Tude The Movie Pentingnya Mencuci Tangan yang Benar, agar sesuai dengan kriteria dan kebutuhan dari pengguna.

Uji ahli media difungsikan sebagai dasar acuan untuk mengetahui kesesuaian secara teknis pada pembuatan Film Animasi 3 Dimensi Tude The Movie - Pentingnya Mencuci Tangan Yang Benar, secara visual dan audio film.

Uji ahli isi dan uji ahli media dilakukan oleh masing-masing 2 orang ahli. Untuk membandingkan dan menyimpulkan jawaban antara 2 ahli, peneliti menggunakan rumus Gregory sebagai berikut.

$$
\text { Validitas Isi }=\frac{\mathrm{D}}{\mathrm{A}+\mathrm{B}+\mathrm{C}+\mathrm{D}}
$$

Uji respon pengguna dilakukan kepada 50 responden anak usia sekolah melalui angket dengan skala Likert. Hasil angket kemudian diklasifikasikan agar memeroleh kriteria respon dari pengguna yang didasarkan pada perhitungan dalam Tabel 2 berikut. 


\section{KคRmดPดTI}

Tabel 2. Kriteria Penggolongan Responden

\begin{tabular}{|c|l|l|}
\hline No. & \multicolumn{1}{|c|}{ Interval } & \multicolumn{1}{|c|}{ Kualifikasi } \\
\hline 1 & $\mathrm{Mi}+1,5 \mathrm{SDi} \leq x$ & Sangat positif \\
\hline 2 & $\begin{array}{l}\mathrm{Mi}+0,5 \mathrm{SDi} \leq x<\mathrm{Mi}+1,5 \\
\mathrm{SDi}\end{array}$ & Positif \\
\hline 3 & $\mathrm{Mi}-0,5 \mathrm{SDi} \leq x<\mathrm{Mi}+0,5 \mathrm{SDi}$ & Netral \\
\hline 4 & $\mathrm{Mi}-1,5 \mathrm{SDi} \leq x<\mathrm{Mi}-0,5 \mathrm{SDi}$ & Negatif \\
\hline 5 & $x<\mathrm{Mi}-1,5 \mathrm{SDi}$ & Sangat Negatif \\
\hline
\end{tabular}

Sumber: [16]

\section{HASIL DAN PEMBAHASAN}

\section{A. Hasil}

Hasil dari pengembangan film animasi 3 dimensi ini didapatkan dengan menggunakan model MDLC (Multimedia Development Life Cycle) yang terdiri dari 6 tahapan berupa Concept, Design, Material Collecting, Assembly, Testing, dan Distribution.

a. Hasil Tahap Concept

Hasil tahap Concept meliputi penetapan judul film animasi, tujuan, jenis media, pedoman cerita, audio, video, dan output.

b. Hasil Tahap Design

Tahap design atau perancangan menghasilkan hasil 3 dimensi dari rancangan awal yang telah dibuat. Perancangan ini meliputi karakter dan latar tempat. Tabel 3 menampilkan hasil implementasi dari perancangan karakter.

Tabel 3. Implementasi Karakter

\begin{tabular}{|c|c|c|}
\hline Karakter & Perancangan Awal & Hasil 3D \\
\hline Tude &
\end{tabular}

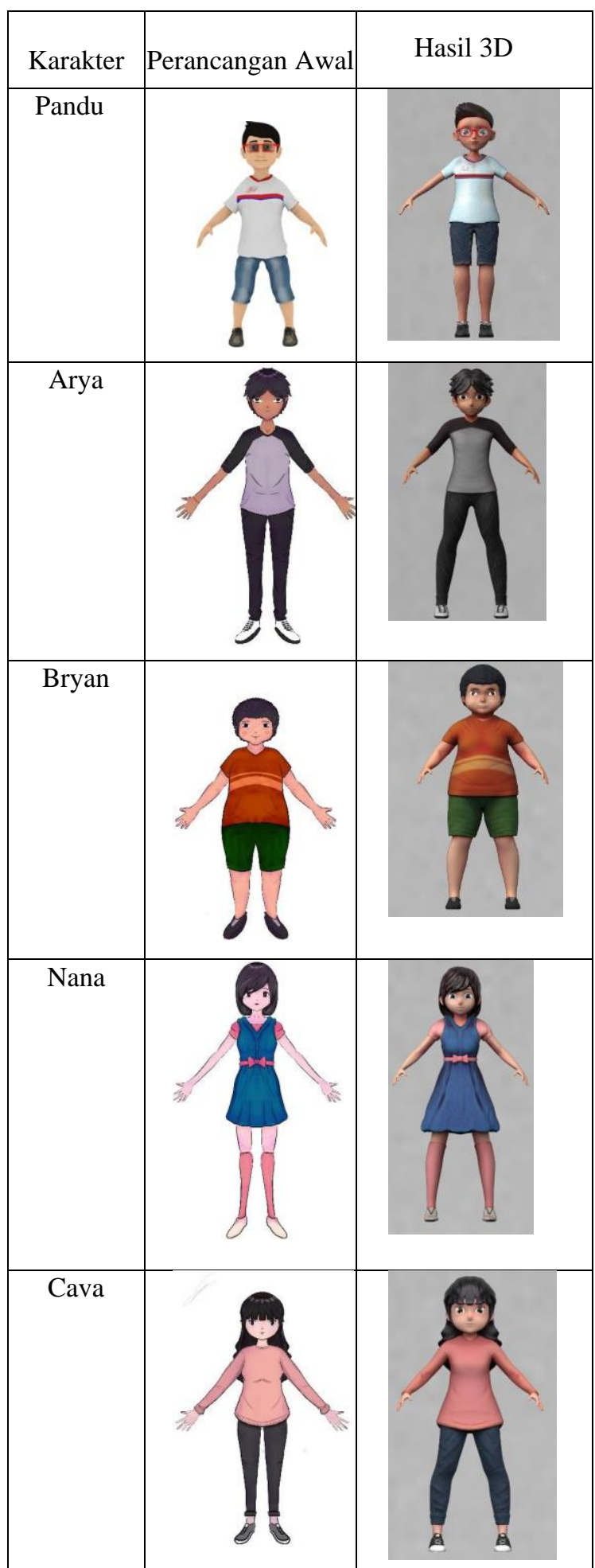


e-ISSN: 2685-7006|p-ISSN: $2252-9063$

Kumpulan Artikel Mahasiswa Pendidikan Teknik Informatika

(KARMAPATI)

Volume 10, Nomor 2, Tahun 2021

\section{KคRMดPคTI}

\begin{tabular}{|c|c|c|}
\hline Karakter & Perancangan Awal & Hasil 3D \\
\hline Dokter & \\
&
\end{tabular}

Tampilan dari hasil implementasi teknik 3D pada rancangan latar belakang dapat dilihat pada Tabel 4 berikut.

Tabel 4. Implementasi Latar Belakang

\begin{tabular}{|c|c|c|}
\hline No. & $\begin{array}{c}\text { Nama Latar Tempat } \\
\text { 1. }\end{array}$ & $\begin{array}{c}\text { Lapangan } \\
\text { Puputan } \\
\text { Badung }\end{array}$ \\
\hline 2. & Tempat Bermain & HD \\
\hline 3. & Puskesmas & \\
\hline
\end{tabular}

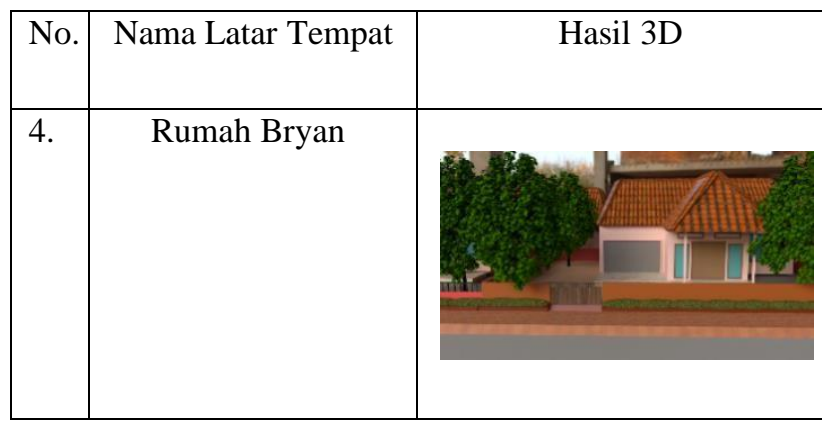

c. Hasil Tahap Material Collecting

Pada tahap material collecting atau pengumpulan bahan, ada beberapa bahan yang dikumpulkan yaitu berupa teks, gambar, animasi, suara serta kebutuhan perangkat keras dan kebutuhan perangkat lunak. Perangkat keras yang dibutuhkan adalah 1 buah komputer dengan spesifikasi Prosesor Intel i5, Ram 16 GB DDR 4, VGA RTX 1660 6gb, SSD 200 GB, dan HDD 1 TB. Kemudian, untuk perangkat lunak (software) yang digunakan dalam pengerjan pembuatan film animasi adalah Autodesk Maya, Substance Painter, Adobe After Effects CS6, Adobe Photoshop CS6, dan Adobe Premiere CS6.

d. Hasil Uji Respon Pengguna

Hasil uji respon pengguna menunjukkan hasil yang sangat baik. Hal ini dikarenakan respon sangat positif dicapai dengan persentase mencapai $98 \%$ dan $2 \%$ lainnya positif. Hal ini menandakan bahwa anakusia sekolah menanggapi Film Animasi 3D Tude The Movie - Pentingnya Mencuci Tangan yang Benar dengan sangat positif. Hasil ini juga menandakan bahwa mereka dapat memahami alur cerita dengan sangat baik, memahami makna yang disampaikan film, memahami pentingnya kesehatan dan mencuci tangan dengan benar, mengetahui nilai-nilai kesehatan sejak dini, dan menganggap film animasi ini sangat menarik dan bermanfaat bagi mereka.

\section{B. Pembahasan}

Pengembangan Film Animasi 3 Dimensi Tude The Movie Pentingnya Mencuci Tangan Yang Benar ini bertujuan untuk memberikan visualisasi mengenai pengetahuan bagaimana pentingnya mencuci tangan yang benar sejak usia dini kepada anak usia sekolah. Hal ini dikarenakan tangan merupakan salah satu anggota tubuh yang mudah menjadi media penularan berbagai penyakit karena selalu menyentuh dan memegang benda yang kebersihannya tidak diketahui [3]. Hasil preobservasi menunjukkan bahwa mayoritas siswa tidak 


\section{KดRMAPคTI}

mengetahui bagaimana cara mencuci tangan dengan benar. Oleh karena itu, film animasi ini dibuat untuk membantu siswa memahami pentingnya mencuci tangan secara rutin dan menyeluruh dengan minimal 20 detik menggunakan sabun dan air bersih yangmengalir dan mengeringkannya dengan kain yang bersih ataupun tisu [3].Dalam proses pengembangannya, Film Animasi 3 Dimensi Tude The Movie Pentingnya Mencuci Tangan Yang Benar ini dibuat dengan metode MDLC (Multimedia Development Life Cycle). Terdapat enam tahapan dalam MDLC, yaitu Concept, Design, Material Collecting, Assembly, Testing, dan Distribution.

Tahap Concept merupakan tahapan pertama yang peneliti lakukan dalamproses pengembangan film animasi ini. Pada tahap ini, peneliti menentukan tujuandari film animasi ini serta mengumpulkan informasi yang diperlukan untuk penetapan konsep awal. Pada tahap ini didapatkanlah hasil bahwa film animasi yang dibuat berjudul Tude The Movie - Pentingnya Mencuci Tangan Yang Benar,yang bertujuan untuk memberikan visualisasi dan pendidikan kepada anak usia sekolah mengenai pentingnya mencuci tangan dengan benar.

Pada tahapan Design, peneliti menetapkan rancangan ide cerita dan storyboardyang meliputi karakter-karakter yang akan berperan dalam film animasi ini dan background yang digunakan sebagai latar film. Adapun karakter-karakter tersebut adalah Tude, Pandu, Bryan, Cava, Nana, Arya, dan Dokter Surya. Adapun latar tempat yang dipilih untuk mendukung storyboard di antaranya adalah lapangan Puputan Badung, tempat bermain, Puskesmas, dan rumah Bryan.

Selanjutnya, tahapan ketiga yang dilakukan adalah Material Collecting dimanapeneliti mengumpulkan seluruh bahan yang diperlukan dalam pembuatan film animasi 3 dimensi ini. Bahan-bahan tersebut berupa teks, animasi, pengisi suara karakter atau dubber, backsound, serta perangkat keras dan perangkat lunak. Adapun perangkat lunak yang digunakan adalah Adobe Photoshop CS6,Adobe Premier CS6, Adobe After Effect CS6, Autodesk Maya, dan Substance Painter.

Tahap keempat yaitu Assembly merupakan tahapan dimana peneliti melakukanpembuatan animasi sesuai dengan yang telah ditetapkan pada tahap Design. Untuk menciptakan alur kerja yang efektif dan efisien, proses assembly ini dilakukan dalam 2 tahapan, yaitu tahap produksi dan pasca produksi. Tahap produksi meliputi modelling, texturing, rigging, skinning, animating, lighting, dan rendering. Proses yang dilalui dalam tahap produksi ini selaras dengan proses produksi yang dilakukan dalam penelitian terdahulu [13] [14]. Kemudian pada tahap pasca produksi, dilakukan perekaman narasi dari film animasi 3 dimensi Tude The Movie - Pentingnya Mencuci Tangan Yang Benar sesuai storyboard dan penggabungan seluruh adegan dan audio yang telah dibuat sebelumnya untuk menjadi satu kesatuan film yang utuh dengan bantuan aplikasi Adobe Premiere ProCS6 dan Adobe Affter Effect.
Selain selaras dalam hal tahapan pada proses produksi, penelitian ini juga sejalan dengan penelitian sebelumnya oleh [13] dan [14] dalam hal tahapan pada Assembly. Penelitian sebelumnya tersebut menggunakan metode Block Diagram yang membagi tahapan pembuatan film animasi menjadi tiga yaitu tahap praproduksi, produksi, dan pasca produksi. Hanya saja, dalam penelitian ini, tahap pra-produksi yang meliputi kegiatan penyusunan ide cerita, karakter, dan storyboard telah dirangkum dalam tahap concept.

Pada tahap keempat yaitu Testing, peneliti melakukan pengujian terhadap film animasi yang dibuat dengan menggunakan 3 jenis pengujian, yaitu uji ahli isi, uji ahli media, dan uji respon pengguna. Uji ahli isi dilakukan oleh 2 orang penguji yang merupakan seorang dokter umum dan seorang bidan. Pengujian ini dilakukan untuk memeroleh kesesuaian isi dengan tujuan film animasi. Hasil pada tahap uji validitas ahli isi peneliti mendapat kesesuaian dengan representasi $100 \%$ yang dilakukan dari 2 kali pengujian

Kemudian, uji ahli media dilakukan oleh 2 ahli pengujian media yang berasal dari Jurusan Teknik Informatika Undiksha. Pengujian ini dilakukan untukmengetahui kesesuaian visual, audio, dan alur cerita pada film animasi. Hasil dari pengujian ahli media mendapat kesesuaian dengan representasi $100 \%$. Peneliti mendapatkan beberapa saran yang kemudian telah dikerjakan sebelum melakukan uji respon pengguna.

Pengujian terakhir, yaitu uji respon pengguna, dilakukan untuk mengetahui kepuasan 50 responden sebagai target dari film animasi ini. Pengujian ini dilakukan dengan cara menyebarkan angket ke anak usia sekolah sebagai responden, yang dilakukan secara online melalui Google Form dengan jumlah pernyataan sebanyak 10 butir. Hasil pengujian menunjukkan bahwa sebanyak $98 \%$ anak menanggapi film animasi ini dengan sangat positif. Kemudian, 2\% lainnya menganggapinya dengan positif. Hal ini menandakan bahwa anak usia sekolah menanggapi Film Animasi 3D Tude The Movie - Pentingnya Mencuci Tangan yang Benar dengan sangat positif. Hasil dari uji respon pengguna ini disajikan dalam Fig. 1.

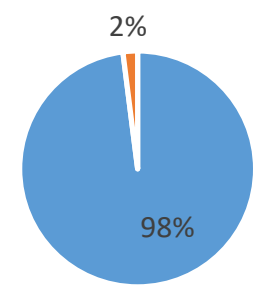

- Sangat Positif - Positif 


\section{KARMAPดTI}

\section{Fig. 1. Hasil Uji Respon Pengguna}

Respon yang sangat positif ini selaras dengan temuan yang didapatkan oleh Pratiwi dkk., [14] dan Pura dkk., [15] yang menemukan bahwa responden jugamenganggapi film animasi 3 dimensi mereka dengan sangat positif. Hanya saja, respon yang diperoleh dalam penelitian ini melalui Film Animasi 3 Dimensi Tude The Movie Pentingnya Mencuci Tangan Yang Benar jauh lebih tinggi dari penelitian sebelumnya karena memeroleh persentase sangat positif sebesar 98\%. Sedangkan, penelitian oleh Pratiwi [14] memeroleh respon penonton yang sangat positif dengan presentase 90,33\% dan Pura dkk., [15] dengan rata-rata persentase $91,44 \%$. Lebih jauh lagi, respon possitif dari anak usia sekolah ini menandakan bahwa media film sekarang bukan hanya sebagai media hiburan melainkan dapat juga sebagai media informasi, pendidikan, promosi, dan masih banyak lainnya [5].

Tahap keenam dan terakhir dalam proses pembuatan film animasi ini adalah Distribution. Pada tahap ini, film animasi yang telah selesai dibuat didistribusikan ke Dinas Kebudayaan Kabupaten Buleleng agar kemudian dapat digunakan untuk mengedukasi anak-anak usia sekolah mengenai pentingnya mencuci tangan denganbenar dan bersih.

Menimbang respon positif dari responden, maka dapat dikatakan bahwa kelebihan dari Film Animasi 3 Dimensi - Tude The Movie Pentingnya Mencuci Tangan Yang Benar ini terletak pada manfaatnya dalam menyampaikan informasi dan edukasi kepada target audience mengenai pentingnya mencuci tangan dengan benar dan bersih. Anak-anak dapat menambah wawasan mereka dengan metode pembelajaran yang menyenangkan, yaitu dengan menonton film animasi.

\section{KESIMPULAN}

Berdasarkan hasil penelitian, pembahasan dan pengujian pada penelitian Pengembangan Film Animasi 3 maka dapat ditarik 2 kesimpulan. Pertama, pengembangan Film Animasi Tude The Movie Pentingnya Mencuci Tangan Yang Benar menggunakan model penelitian MDLC (Multiemdia Development Life Cycle) dengan menggunakan software Autodesk Maya serta software penunjang lainnya seperti Substance Painter, Adobe AfterEffects Cs6, Adobe Photoshop Cs6, Adobe Premiere CS 6. Kedua, respon dari anak usia sekolah akan Film Animasi 3D Tude The Movie Pentingnya Mencuci Tangan Yang Benar sangatlah positif, yang ditunjukkan dengan persentase sangat positif sebesar $98 \%$ dan positif sebesar $2 \%$.

\section{REFERENCES}

[1] Enterprise, J. (2020). Dasar - Dasar Animasi Komputer. Jakarta : PT Elex Media Komputindo.

[2] Willsen, L (2017). Cepat mahir Membuat Film Animasi 3D. Jakarta: PT Elex Media Komputindo.

[3] Anies. (2020). COVID-19: Seluk Beluk Corona Virus Yang Wajib Dibaca. Jogjakarta : ARRUZZ MEDIA.

[4] Risnawati, G. (2016). Faktor Determinan Perilaku Cuci Tangan Pakai Sabun (CTPS) pada Masyarakat di Tanah Kalikedinding. The Indonesian Journal of Health Promotion and Health Education, 4(1), 70-81.

[5] Wardiana, I. N. A., Piarsa, I. N., \& Sasmita, G. M. A. (2015). Rancang Bangun Film Animasi 3 Dimensi Sejarah Pura Tanah Lot. E-Journal SPEKTRUM, 2(4), 20-25.

[6] Ariani, R., \& Festiyed. (2019). Analisis Landasan Ilmu Pengetahuan dan Teknologi Pendidikan dalam Pengembangan Multimedia Interaktif. Jurnal Penelitian Pembelajaran Fisika, 5(2), 155-162.

[7] Siswati, \& Damayanti, E. (2019). Animasi 2D dan 3D. SMK/MAK Kelas $X I$.

[8] Gunawan, B. (2012). Nganimasi Bersama Mas Be! Jakarta: PT Elex Media Komputindo.

[9] Zaharuddin, G., \& Djalle. (2007). The Making of 3D Animation Movie Using 3D Studio Max. Bandung: Informatika.

[10] Aditya. (2009). Trik Dahsyat Menjadi Animator 3D Handal. Yogyakarta : Andi.

[11] Nana-Syaodih, S. (2009). Metode Penilitan Pendidikan. Bandung: PT. Remaja Rosdakarya.

[12] Sugiyono. (2018). Metode Penelitian Kuantitatif, Kualitatif dan $R \& D$ Bandung: Alfabeta.

[13] Antara, I. M. Y., Crisnapati, P. N., Agus, I. M. W., \& Sunarya, I. M. G. (2019). Pengembangan Film Animasi 3 Dimensi "Tude the Movie Petualangan Si Rina (Tertangkapnya Burung Jalak Bali).” Kumpulan Artikel Mahasiswa Pendidikan Teknik Informatika (KARMAPATI), 7(3), 214. https://doi.org/10.23887/karmapati.v7i3.19788

[14] Pratiwi, P. Y., Darmawiguna, I. G. M., \& Sunarya, I. M. G. (2016). Pengembangan Film Animasi 3 Dimensi Kehidupan Pada Zaman Prasejarah. 5(1).

[15] Putra, I. P. A. S., Darmawiguna, I. G. M., \& Putrama, I. M. (2017). Film Seri Animasi 3D Belajar Bahasa IndonesiaBersama Made Sebagai Media Pembelajaran Bahasa Indonesia Untuk Penutur Asing Di Undiksha. Kumpulan Artikel Mahasiswa Pendidikan Teknik Informatika, 6(1), 20. https://doi.org/10.23887/karmapati.v6i1.9051.

[16] Candiasa, I. M. (2011). Pengujian Instrumen Disertai Aplikasi Iteman dan Bigsteps. Singaraja : Universitas Pendidikan Ganesha.

[17] I. G. B. Subawa, I. N. E. Mertayasa, K. Agustini, and D. S. Wahyuni, "Design of user satisfaction evaluation instrument of informatics engineering education graduates, faculty of engineering and vocational, universitas pendidikan ganesha," J. Phys. Conf. Ser., vol. 1810, no. 1, 2021, doi: 10.1088/1742-6596/1810/1/012067 